\title{
Effect of different protein supply on growth of three populations of a crab adapted to low energy diets
}

\author{
Claudia Bas*, Tomás Luppi and Eduardo Spivak
}

\begin{abstract}
Juvenile individuals of the crab Neohelice granulata (Brachyura: Grapsoidea: Varunidae) were grown in laboratory using five artificial diets containing 3, 6, 12, 18 and $24 \%$ of crude protein and $3 \%$ of lipids during 7 months. Crabs belonged to three different populations. Two of them, San Antonio Oeste (SAO) and Riacho San José (RSJ) are close; they are not genetically differentiated but vary in morphological traits. The third, Mar Chiquita (MC), is far and genetically differentiated from the other two, but morphological traits of their individuals are intermediate. The growth (absolute and relative size change, final body mass), molting frequency, hepatosomatic index of individuals, as well as the Carbon and Nitrogen content and histological structure of their digestive glands, were analyzed. Mar Chiquita individuals differed from one or both of the other two populations. Time to first molt was significantly longer in MC, final size was significantly smaller in MC than RSJ and hepatosomatic index was significantly lower in MC compared to SAO and RSJ. San Antonio Oeste and RSJ individuals never differed. Furthermore, in all cases crabs were able to molt and growth with all diets, although growth in size and mass were higher, and intermolt periods shorter, when diets contained higher percentages of protein. It is concluded that species is well adapted to low quality food sources and it is suggested that size differences previously observed between SAO and RSJ crabs are due to phenotypic plasticity, while differences with MC population are governed by evolutionary adaptation to different food availability.
\end{abstract}

Keywords: Neohelice, Diet, Growth, Argentine

\section{Background}

Species with broad distributions are expected to show morphological, physiological or behavioral differences in response to local conditions that could be the result of phenotypic plasticity, the capacity of a single genotype to produce variable phenotypes in different environments when genetic differentiation is absent [22], or local adaptation if gene flow among populations is restricted [10]. The last process is considered common in terrestrial and freshwater species, but it was not until recently recognized as frequent in marine species, even those with planktonic dispersal [24]. For example, differences in nutritional environment (i.e.: quality and/or quantity of

*Correspondence: ccbas@mdp.edu.ar

Laboratorio de Invertebrados, Instituto de Investigaciones Marinas y Costeras (IIMyC), Universidad Nacional de Mar del Plata and Consejo Nacional de Investigaciones Científicas y Tecnológicas (CONICET), CC1260, 7600 Mar del Plata, Buenos Aires, Argentina food) among populations of a species may lead animals to exhibit different strategies of digestive physiology and/ or morphology; in addition, the ability to cope with temporal or spatial changes in the nutritional environment may vary also among those populations [25]. Particularly, nitrogen is the most common limiting factor among herbivorous [9], that have developed different strategies to cope with such a low quality food source. Among decapod crustaceans, many crab species of different families developed the skill to rely almost exclusively on plants, and they share some common traits related to physiology, metabolism, behavior and life history [17].

Neohelice granulata (previously known as Chasmagnathus granulatus and C. granulata) is a semiterrestrial burrowing crab endemic from the Southwestern Atlantic, distributed from southern Brazil to northern Patagonia in Argentina along $20^{\circ}$ latitude range. Adults inhabit intertidal mudflats and marshes, from oligohaline to 
hyperhaline environments, where they feed mainly on leaves and sediment [3]; its life cycle includes a typical marine planktonic larval development (four zoeae and a megalopa stage). The genetic and morphometric pattern of the species was studied by Ituarte et al. [8] in populations along its complete geographical distribution. They found strong genetic differentiation consistent with an isolation-by-distance pattern, with gene flow occurring mainly between neighbor populations. Morphological differences instead, did not follow the same pattern.

Two close populations of $N$. granulata, San Antonio Oeste (SAO) and Riacho San José (RSJ) are located in bays separated by only $190 \mathrm{~km}$ that drain into San Matías gulf (Northern Patagonia), in the southernmost limit of the geographical distribution of the species (Fig. 1); both habitats differ mainly in vegetation [6] and in granulometry and organic matter content of sediments: substrate was hard in SAO with a high proportion of gravel and scarce organic matter whereas it was soft in RSJ, with twice as silt and clay and higher organic matter content [26]. Both populations appeared as genetically homogeneous but with clear morphological differences [8]. SAO population has been previously studied [2] and compared to Mar Chiquita lagoon (MC, Fig. 1), a northern, genetically separated and extensively studied population ([3, 7, $14,15,19,20]$ and references thereof). Individuals from SAO were smaller and presented a shorter reproductive period and these differences were attributed, at least in part, to food availability. A preliminary comparative study of SAO and RSJ populations found that in the latter, crabs of both sexes were larger, fecundity and reproductive output were higher, the size at maturity of females was smaller and its range shorter, and burrows were longer and wider; in fact, RSJ specimens had the largest sizes (carapace width, males: $38.3 \mathrm{~mm}$; females: $35.5 \mathrm{~mm}$ ) and the highest reproductive output $(12.15 \pm 1.54)$ reported for the species [26].

On the basis of the available information, we hypothesized that differences between SAO and RSJ are product of a plastic response to different food conditions and that differences between those populations and MC are due to local adaption. Under this rationale, we expected that crabs from SAO and RSJ populations faced with the same food conditions should have the same response regarding growth and nutritional state since they do not differ genetically. This response would be different in individuals from MC, a genetically different population evolved in other feeding conditions. The parameters used to evaluate growth were intermolt period, size increment, proportional growth in successive molts, and dry mass of organic components of the body. The digestive gland condition was used to evaluate the nutritional state, a procedure widely applied in decapod crustaceans [28]. Specifically, the weight of the digestive gland and the microscopic anatomy of their tubules were considered. At the same time we wanted to evaluate if this species is well adapted to low protein diets i.e.: if crabs may survive, molt, growth and accumulate food when faced to protein restrictions. To test both questions we compared growth parameters and digestive gland condition among individuals from the three populations fed in laboratory with artificial diets, starting from very low protein content to intermediate values, with constantly low lipids.

\section{Methods}

\section{Crab collection}

Juvenile males and females of $N$. granulata between 8 and $11 \mathrm{~mm} \mathrm{CW}$ (maximum carapace width) were collected on January 22, 23 and 25, 2013 at RSJ, SAO and MC respectively (Fig. 1). Crabs were immediately transported

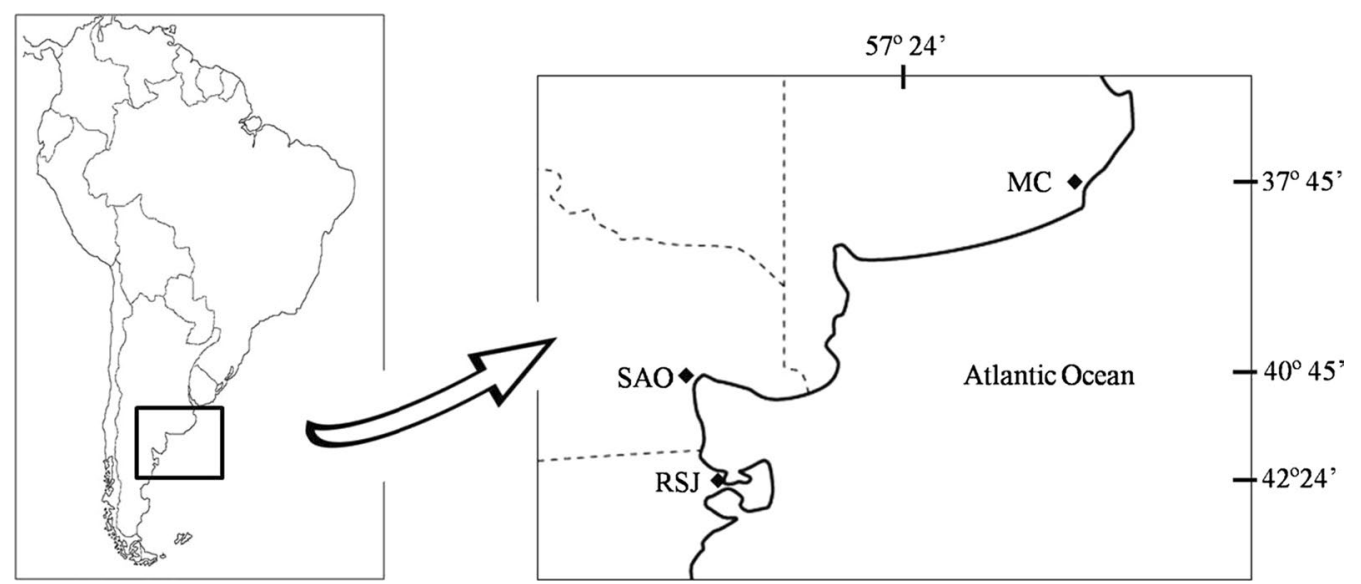

Fig. 1 Geographic location of the three sampled populations. MC Mar Chiquita, SAO San Antonio Oeste, RSJ Riacho San José 
to laboratory, sexed, their CW measured with a Vernier caliper, and assigned to one of the five experimental diets, trying to keep similar proportion of each sex.

\section{Diet formulation}

Previous studies indicated that this species, in those sites where it was evaluated, rely on low quality (energy and protein content) diets of saltmarsh plant's leaves and/or superficial mudflat sediment, containing in average, $4 \%$ of organic matter [3]. Based on this information, diets were prepared starting from very low protein content. Five experimental diets (A, B, C, D and E) were formulated and contained 3, 6, 12, 18 and $24 \%$ of crude protein (CP), respectively. Lipid content was kept approximately constant at $3 \%$ and carbohydrates proportion varied to maintain energy content at 12,000 $\mathrm{mJ} / \mathrm{kg}$ (Table 1).

\section{Feeding trials}

Crabs were reared in individual perforated plastic cages (10 $\mathrm{cm}$ diameter) randomly assigned to one of five aquaria $(70 \times 40 \times 20 \mathrm{~cm})$. Each aquarium containing seven crabs of each population (21 total crabs) that received one of the five diets. Aquaria containing aerated marine water were kept in a room at $20{ }^{\circ} \mathrm{C}$ and 12:12 L:D photoperiod, their position in the room was changed daily, and water was changed twice a week. Crabs were fed daily with at least $0.035 \mathrm{~g}$ of pellets, containing

Table 1 Ingredients, proximate composition and energy content of the experimental diets

\begin{tabular}{|c|c|c|c|c|c|}
\hline \multirow[t]{2}{*}{ Ingredients (g) } & \multicolumn{5}{|l|}{ Diet } \\
\hline & 1 & 2 & 3 & 4 & 5 \\
\hline Fishmeal $^{\mathrm{a}}$ & 49.3 & 98.8 & 197.8 & 296.8 & 395.8 \\
\hline Cod-liver oil & 24.7 & 19.4 & 8.8 & 0 & 0 \\
\hline Corn starch ${ }^{b}$ & 508.6 & 467.3 & 384.7 & 297.8 & 190.7 \\
\hline $\mathrm{CMC}^{\mathrm{C}}$ & 20 & 20 & 20 & 20 & 20 \\
\hline Na alginate & 50 & 50 & 50 & 50 & 50 \\
\hline Vitamins + minerals $^{d}$ & 10 & 10 & 10 & 10 & 10 \\
\hline Bentonite & 337.4 & 334.5 & 328.7 & 325.4 & 333.5 \\
\hline Total & 1000 & 1000 & 1000 & 1000 & 1000 \\
\hline \multicolumn{6}{|c|}{ Proximate composition (\%) } \\
\hline Crude protein & 3 & 6 & 12 & 18 & 24 \\
\hline Lipids & 3 & 3 & 3 & 3.1 & 4.2 \\
\hline Carbohydrates & 58.8 & 54.7 & 46.4 & 37.8 & 27.1 \\
\hline Dry matter & 98 & 97.5 & 97.6 & 98.1 & 98.4 \\
\hline Ash & 36.3 & 40.4 & 45.6 & 52.1 & 58.2 \\
\hline Gross energy (kJ/g) & 1200 & 1200 & 1200 & 1200 & 1200 \\
\hline
\end{tabular}

a $60.6 \%$ crude protein, $10.7 \%$ lipids, $0 \%$ carbohidrates

b $99.7 \%$ carbohidrates, $0.3 \%$ protein

c Carboxymethylcellulose sodium salt (Sigma-Aldrich ${ }^{\circledR}$, USA)

d Centrum multivitamins multiminerals (Wyeth ${ }^{\circledR}$, Canada)
$100 \mathrm{cal}$, the daily energy requirements estimated by Klein Breteler [11] for juvenile Carcinus maenas of similar size.

\section{Crab processing and data obtaining}

Crabs were checked for molt every day and date and size recorded. $\mathrm{CW}$ was measured after total hardening 2 days after molt. The relative size increment at molt (CW after molt $-\mathrm{CW}$ before molt/CW before molt), the total size increment (final CW - initial CW/initial CW), the time to the first molt from the beginning of the experiment, and the intermolt period (days between successive molts) were calculated. Crabs were sacrificed 15 days after their 3rd molt or after a maximum period of culture of 7 months even if they have molted only twice. Individuals were killed by freezing some minutes and digestive gland extracted. A small portion of digestive gland of each crab was weighted, then preserved in Davidson's fixative $24 \mathrm{hs}$ and conserved in $70 \%$ ethanol until histological processing. Digestive glands were weighted (wet mass) and then crabs and their digestive glands were dried $48 \mathrm{hs}$ at $60{ }^{\circ} \mathrm{C}$ in order to obtain their respective dry mass (DM). To estimate the hepatosomatic index (HI: digestive gland $\mathrm{DM} / \mathrm{crab} \mathrm{DM}$ ), the dry mass of the small fractions used for histological analysis was estimated from the wet mass corrected for the water content and added to each digestive gland. Dried digestive glands from 5 crabs of each population fed with diets containing low $\mathrm{CP}(\operatorname{diet} \mathrm{A})$ and high $\mathrm{CP}$ (diet $\mathrm{D}+\mathrm{E}$, see below) were analyzed for $\mathrm{C}$ and $\mathrm{N}$ content with an elemental Analyzer (Exeter CE 440). Individuals from each population fed with diets $\mathrm{D}$ and E were randomly used since some samples of digestive glands from individuals fed with diet $\mathrm{E}$ spoiled and no differences appeared at any measured parameter between $D$ and E. Crabs were burned to ashes to estimate the organic content (ash free dry mass or AFDM) as: crab DM-ashes DM. The proportion of the DM of crabs attributable to organic components (AFDM) was made independent of crabs' size by dividing each AFDM by the corresponding $\mathrm{CW}$ (relative $\mathrm{AFDM}=\mathrm{AFDM} / \mathrm{CW}$ ) before comparing among diets and populations. Also, the relative DM of digestive gland (relative DGDM $=\mathrm{DGDM} / \mathrm{CW}$ ) was calculated. Histological structure of digestive glands was observed in previously fixed tissues embedded in paraffin and stained with current Hematoxylin-Eosin protocol.

\section{Data analysis}

Comparisons of intermolt period, size increment and proportional growth in the successive molts were made with Two-Way ANOVAs with repeated measures, with population and diet as factors. Analysis of initial size, time to the first molt, $\mathrm{C}, \mathrm{N}$ and organic matter contents were made with Two Way ANOVAs with population and diet as factors. A posteriori comparisons were made 
following Holm-Sidak procedures. Normality and homoscedasticity were evaluated with Kolmogorov-Smirnov and Levene's test respectively.

\section{Results}

All crabs survived the experimental period. The size at the beginning of the experiment was in average $9.71 \pm 0.8 \mathrm{~mm} \mathrm{CW}$, with no differences among diets $\left(\mathrm{F}_{4,90}=0.91 ; \mathrm{p}=0.46\right)$ or populations $\left(\mathrm{F}_{2,90}=0.89\right.$; $\mathrm{p}=0.41)$ and no interaction existed between factors $\left(\mathrm{F}_{8,90}=0.78 ; \mathrm{p}=0.62\right)$. All individuals molted at least twice; $68 \%$ of MC, $89 \%$ of SAO and $91 \%$ of RSJ individuals molted three times during the experimental period. The time until the first molt in laboratory varied among populations (Table 2), being significantly longer in MC (average time $44.6 \pm 12.5$ days) than in the other two populations (average time $34.6 \pm 10.9$ days) $(t=4.93$, $\mathrm{p}<0.05$ and $\mathrm{t}=3.16, \mathrm{p}<0.05 ; \mathrm{MC}$ vs SAO and MC vs RSJ respectively), and among diets (Table 2); time was shorter in diets enriched in protein, but only diet A with $\mathrm{D}$ and $\mathrm{E}$ differed significantly $(\mathrm{t}=3.45, \mathrm{p}<0.01$ and $\mathrm{t}=2.86, \mathrm{p}<0.01$ respectively).

The first and second intermolt periods registered in laboratory were not different among populations but they were among diets, with a tendency similar to the described for the time to the first molt, being also the second intermolt period significantly longer than the first one (Table 3; Fig. 2).

The post-molt size increased in successive molts depending on diet but not on population and differences among diets became increasingly significant with molts (Table 4; Fig. 3).

The relative size increment at molt (Table 5; Fig. 4) was in general the same for the three populations, with differences among successive molts: a higher proportional increase was observed in the first and second molt (16.7 \% in average), than in the third molt (14.7\% in average). Nevertheless, a significant interaction existed among populations and successive molts. Furthermore,

Table 2 Two-way ANOVA showing the effect and interactions among time to first molt of juveniles (dependent variable), diet (3-24\% protein content) and population (Mar Chiquita, San Antonio and Riacho San Jose) (independent factors)

\begin{tabular}{lrrrll}
\hline Effect & \multicolumn{1}{l}{ SS } & df & \multicolumn{1}{c}{ MS } & F & p \\
\hline Diet (1) & 2227.1 & 4 & 556.8 & 3.047 & $* *$ \\
Population (2) & 2565.0 & 2 & 1282.5 & 7.018 & $* * *$ \\
$1 \times 2$ & 100.5 & 8 & 12.6 & 0.068 & ns \\
Error & $15,531.7$ & 85 & 182.7 & &
\end{tabular}

ns non-significant, $d f$ degree of freedom

Significant $P$ values: ${ }^{* * *} P<0.001,{ }^{* *}<0.01$
Table 3 Two-way repeated measures ANOVA showing the effect and interactions among intermolt period of juveniles at successive molts (dependent variable) (RM), diet (3-24 \% protein content) and population (Mar Chiquita, San Antonio and Riacho San Jose) (independent factors)

\begin{tabular}{lrrrrr}
\hline Effect & \multicolumn{1}{c}{ SS } & df & \multicolumn{1}{c}{ MS } & F & p \\
\hline Diet (1) & 6105.5 & 4 & 1526.4 & 6.81 & $* * *$ \\
Population (2) & 289.9 & 2 & 145.0 & 0.64 & ns \\
$1 \times 2$ & 749.7 & 8 & 93.7 & 0.41 & ns \\
Error & $14,339.7$ & 64 & 224.1 & & \\
RM (3) & 8425.6 & 1 & 8425.6 & 85.58 & $* * *$ \\
$1 \times 3$ & 109.6 & 4 & 27.4 & 0.27 & ns \\
$2 \times 3$ & 530.6 & 2 & 265.3 & 2.63 & ns \\
$1 \times 2 \times 3$ & 368.2 & 8 & 46.0 & 0.45 & ns \\
Error & 6451.2 & 64 & 100.8 & & \\
\hline
\end{tabular}

ns non-significant, $d f$ degree of freedom

Significant $P$ values: ${ }^{* *} P<0.001,{ }^{* *}<0.01$

differences among diets were always significant: individuals from low protein diets grew less, both in absolute and relative terms, than those from richest diets. Maximal relative increment (diets D and E) was in average $19 \%$ in the first and second molt and $16 \%$ in the third molt and minimal increments (diet 1) averaged $13.8 \%$ in the first and second molt and $11.3 \%$ in the third molt.

When the total size increment was compared, significant differences appeared among populations and diets $\left(\mathrm{F}_{4,69}=17.54 ; \mathrm{p}<0.05\right.$ and $\mathrm{F}_{2,90}=3.17 ; \mathrm{p}<0.001$ respectively) and no interaction existed between factors

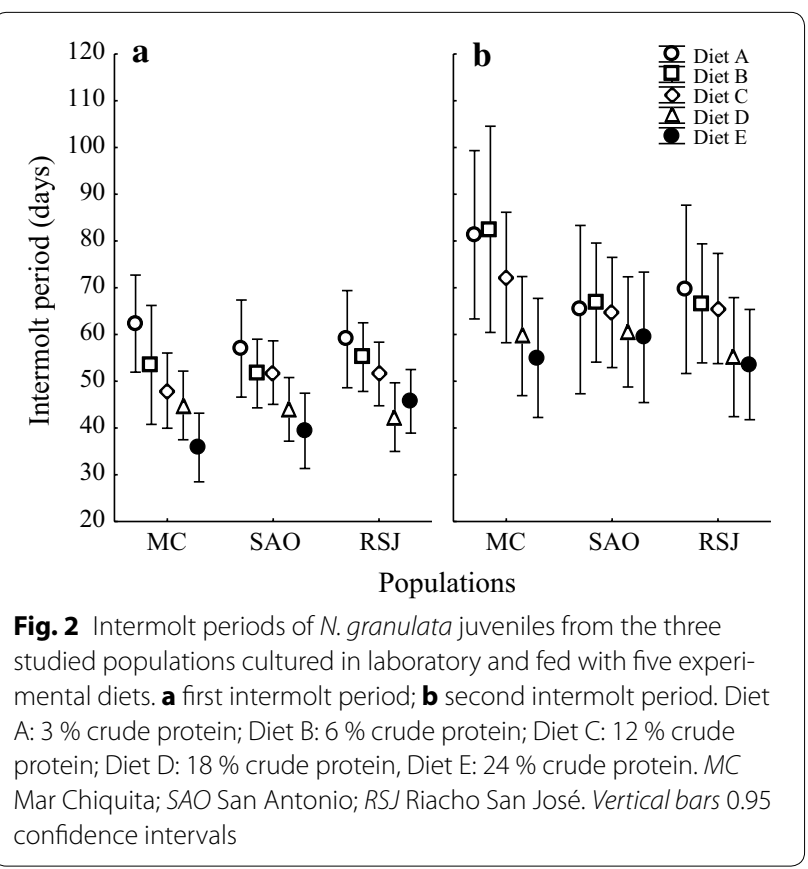


Table 4 Two-way repeated measures ANOVA showing the effect and interactions among carapace width of juveniles at successive molts (dependent variable) (RM), diet (3-24\% protein content) and population (Mar Chiquita, San Antonio and Riacho San Jose) (independent factors)

\begin{tabular}{lrrrrr}
\hline Effect & \multicolumn{1}{c}{ SS } & df & \multicolumn{1}{c}{ MS } & F & p \\
\hline Diet (1) & 87.91 & 4 & 21.98 & 8.88 & $* * *$ \\
Population (2) & 2.60 & 2 & 1.30 & 0.53 & ns \\
$1 \times 2$ & 11.86 & 8 & 1.48 & 0.60 & ns \\
Error & 168.27 & 68 & 2.47 & & \\
RM (3) & 509.46 & 2 & 254.73 & 3548.46 & $* * *$ \\
$1 \times 3$ & 11.84 & 8 & 1.48 & 20.62 & $* * *$ \\
$2 \times 3$ & 0.06 & 4 & 0.02 & 0.22 & ns \\
$1 \times 2 \times 3$ & 1.05 & 16 & 0.07 & 0.92 & ns \\
Error & 9.76 & 136 & 0.07 & & \\
\hline
\end{tabular}

ns non-significant, $d f$ degree of freedom

Significant $P$ values: ${ }^{* *} P<0.001,{ }^{* *}<0.01$

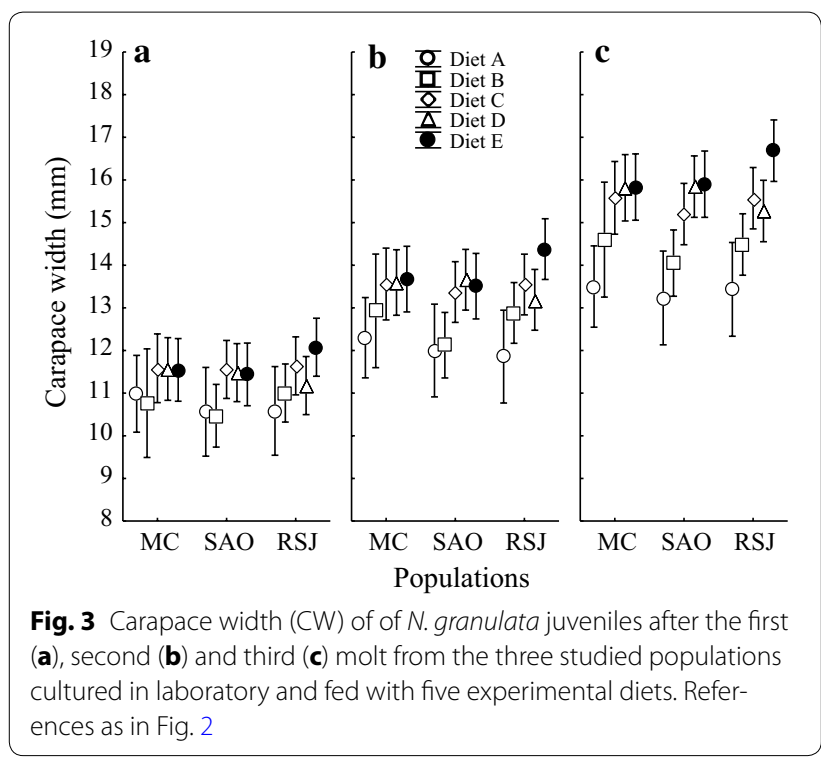

$\left(\mathrm{F}_{8,69}=1.08 ; \mathrm{p}=0.38\right)$. The a posteriori comparisons revealed differences between $\mathrm{MC}$ and RSJ, with the lesser and the higher average increment respectively. With regard to diets, diet $\mathrm{A}$ differed from the others and diet $\mathrm{B}$ and $\mathrm{C}$ differed from diet $\mathrm{E}$ (Fig. 5).

The relative AFDM differed significantly among diets but not among populations $\left(\mathrm{F}_{4,75}=44.36 ; \mathrm{p}<0.001\right.$, $\mathrm{F}_{2,75}=1.22 ; \mathrm{p}=0.30$ and $\mathrm{F}_{8,75}=1.96 ; \mathrm{p}=0.06$ for diet, population and their interaction respectively) (Fig. 6a). The same result was obtained when individuals that molted only twice (see below) were not taken into account. All diets differed from each other, except $C$ from $\mathrm{D}$ and $\mathrm{D}$ from $\mathrm{E}$. The relative AFDM of individuals fed with diet $\mathrm{E}$ doubled that of individuals fed with diet $\mathrm{A}$.
Table 5 Two-way repeated measures ANOVA showing the effect and interactions among molt increment of juveniles at successive molts (dependent variable) (RM), diet (3-24\% protein content) and population (Mar Chiquita, San Antonio and Riacho San Jose) (independent factors)

\begin{tabular}{lrrrrr}
\hline Effect & \multicolumn{1}{l}{ SS } & df & \multicolumn{1}{c}{ MS } & F & $\mathbf{p ~}$ \\
\hline Diet (1) & 588.42 & 4 & 147.10 & 16.60 & $* * *$ \\
Population (2) & 52.53 & 2 & 26.27 & 2.96 & ns \\
$1 \times 2$ & 67.82 & 8 & 8.48 & 0.95 & ns \\
Error & 602.29 & 68 & 8.86 & & \\
RM (3) & 237.48 & 2 & 118.74 & 13.14 & $* * *$ \\
$1 \times 3$ & 81.45 & 8 & 10.18 & 1.12 & ns \\
$2 \times 3$ & 108.05 & 4 & 27.01 & 2.99 & $*$ \\
$1 \times 2 \times 3$ & 134.11 & 16 & 8.38 & 0.92 & ns \\
Error & 1228.23 & 136 & 9.03 & & \\
\hline
\end{tabular}

ns non-significant, $d f$ degree of freedom

Significant $P$ values: ${ }^{* * *} P<0.001,{ }^{* *}<0.01,{ }^{*}<0.05$

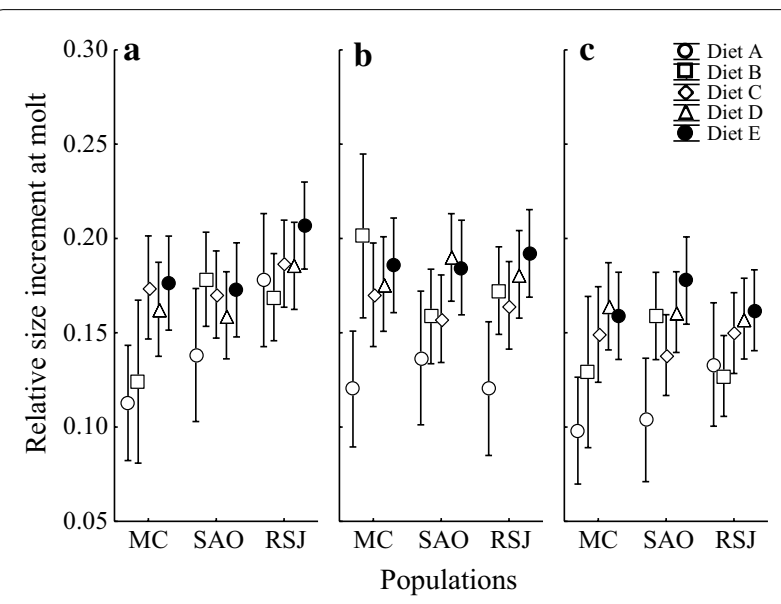

Fig. 4 Percent increment per molt of $N$. granulata juveniles after the first (a), the second (b) and the third (c) molts from the three studied populations cultured in laboratory and fed with five experimental diets. References as in Fig. 2

The relative DM of digestive gland differed significantly among diets but not populations $\left(\mathrm{F}_{4,75}=6.78 ; \mathrm{p}<0.001\right.$, $\mathrm{F}_{2,75}=0.08 ; \mathrm{p}=0.92$ and $\mathrm{F}_{8,75}=0.45 ; \mathrm{p}=0.88$ for diet, population and their interaction respectively). Digestive gland relative DM of individuals from diet A differed from all others (Fig. 6b).

Hepatosomatic indexes (HSI) calculated from all individuals at the end of the experiment differed significantly among diets $\left(\mathrm{F}_{4,85}=12.25 ; \mathrm{p}<0.001\right)$ but not populations $\left(\mathrm{F}_{2,85}=0.37 ; \mathrm{p}=0.69\right)$ and with no interaction between factors $\left(\mathrm{F}_{8,85}=0.91 ; \mathrm{p}=0.5\right)$ (Fig. 7a). The highest HSI was registered in individuals fed with diets $\mathrm{A}$ and $\mathrm{B}$, the lowest in individuals fed with diets $\mathrm{D}$ 


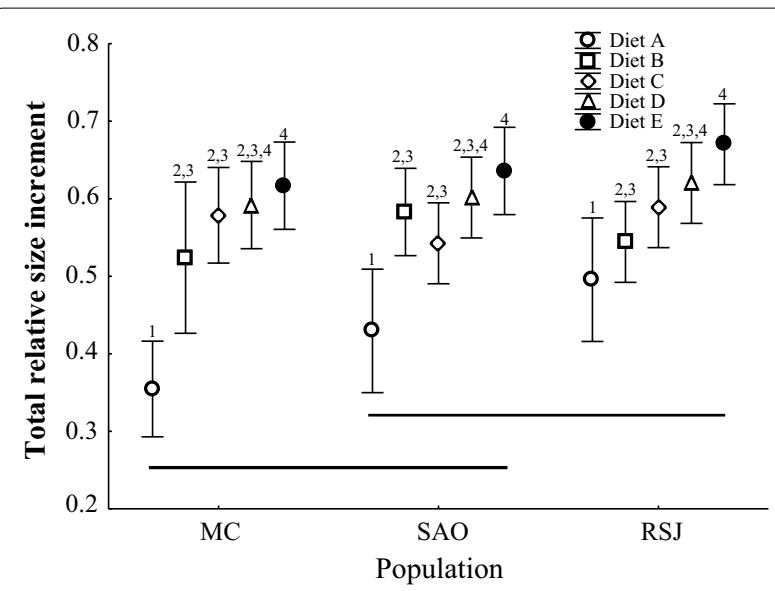

Fig. 5 Total proportional increment of N. granulata juveniles from the three studied populations cultured in laboratory and fed with five experimental diets. References as in Fig. 2. Numbers on bars indicate the a posteriori paired comparisons among diets (Holm-Sidak test); same number signifies no differences between pairs ( $p>0.05)$. Horizontal bars indicate results of a posteriori paired comparisons (Holm-Sidak test) among populations; bars join no different groups $(p>0.05)$

and $\mathrm{E}$ and individuals fed with diet $\mathrm{C}$ had an intermediate value. This analysis included individuals that molted three times, the last molt between 15 and 30 days before the end of experiment, and those that had molted only twice at the end of the experiments. This last group molted between 51 and 107 days before the end of the experiments and corresponded mainly to individuals from diets A and B. Thus, this group had a grater average lapse since the last molt. When those individuals were excluded from the HIS analysis, all groups were similar in time since the last molt $\left(\mathrm{F}_{4,81}=0.53 ; \mathrm{p}=0.70\right.$ and $\mathrm{F}_{2}$, ${ }_{81}=0.49 ; \mathrm{p}=0.61$ for diet and population respectively) and differences appeared in HSI among populations too $\left(\mathrm{F}_{2,67}=6.42 ; \mathrm{p}<0.01\right)$, having $\mathrm{MC}$ a lower HSI than the other two sites (Fig. 7b).

No differences appeared among populations or diets in Carbon content $\left(\mathrm{F}_{2,21}=2.37 ; \mathrm{p}=0.11, \mathrm{~F}_{1,21}=0.55\right.$; $\mathrm{p}=0.46$ and $\mathrm{F}_{2,21}=0.19 ; \mathrm{p}=0.82$ for population, diet and their interaction respectively;), that accounted for more than half of the digestive gland dry weight (average $57.8 \pm 3.2 \%)$. Nitrogen content instead, was scarce and differed between diets $\left(\mathrm{F}_{1,21}=12.66 ; \mathrm{p}<0.01\right)$ but not among populations $\left(\mathrm{F}_{2,21}=1.14 ; \mathrm{p}=0.33\right)$, being significantly higher in crabs of the three populations fed with high protein diets (diets D and E) (average $5.24 \pm 0.8 \%$;) compared to crabs fed with diet A (average $3.88 \pm 0.8 \%$ ), and with no interaction between factors $\left(\mathrm{F}_{2,21}=0.01\right.$; $\mathrm{p}=0.98$.

The appearance of digestive glands tubules of all analyzed individuals was that of a normal tissue. The

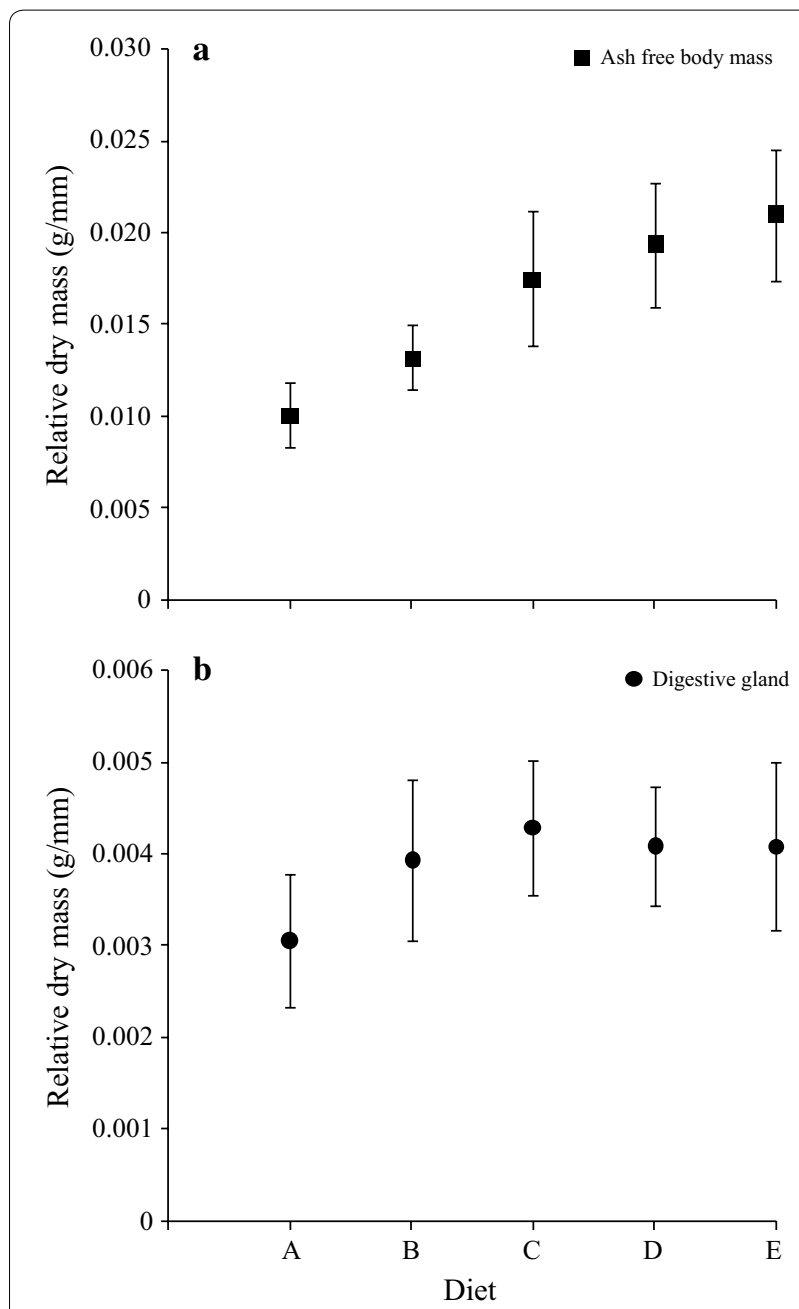

Fig. 6 a Dry mass relative to size of organic mass (AFDM/CW) and b digestive gland (digestive gland DM/CW) of $N$. granulata juveniles from the three studied populations cultured in laboratory and fed with five experimental diets. Vertical bars standard deviation. References as in Fig. 2

following cell types were observed in sections from crabs fed with all the experimental diets: resorptive (R), fibrillar (F), blister-like (B) and embryonic (E) cells. In all cases $\mathrm{R}$ cells were the most abundant and $\mathrm{F}$ and $\mathrm{B}$ cells were interspersed with them. E cells appeared at the blind end of tubules. Pyknotic nuclei were not observed and single large or numerous small vacuoles were observed in B and $\mathrm{R}$ cells respectively. Apical border of tubular cells presented a clear microvilleus border and peritrophic membranes appeared in most of tubules' lumens (Fig. 8).

\section{Discussion}

Behavioral, physiological and metabolic differences among populations may result in differences in growth and energy storage. Even when no sharp differences 

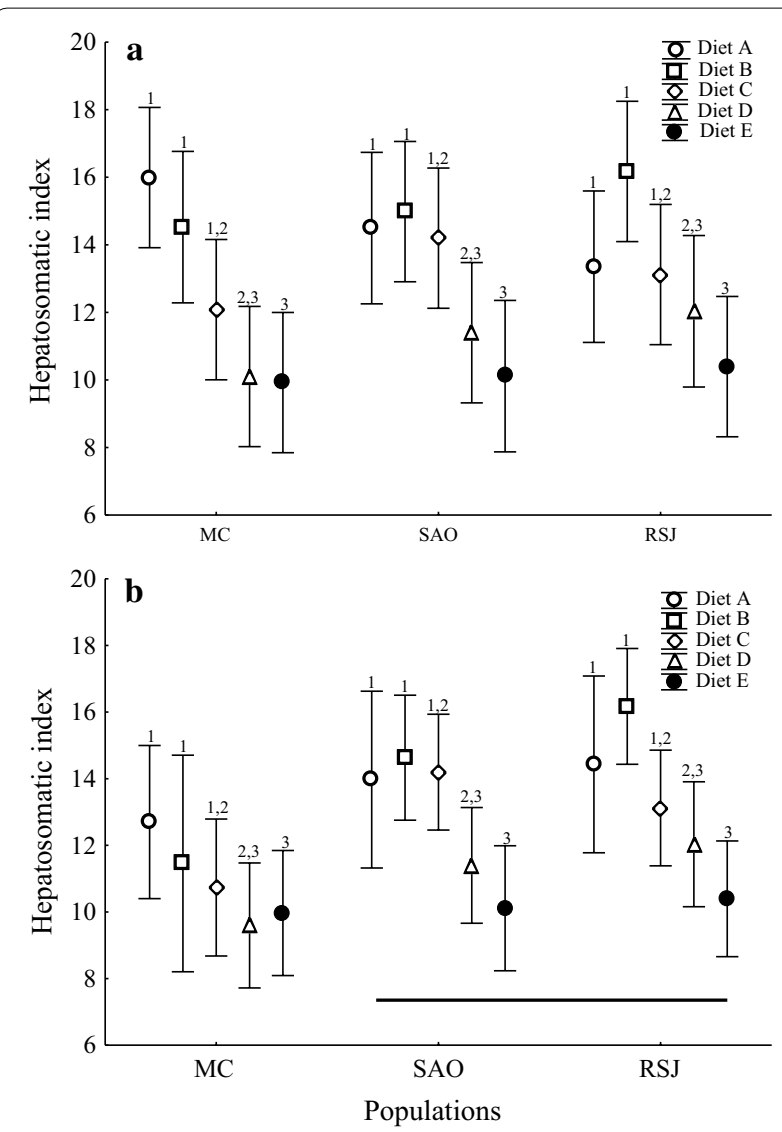

Fig. 7 Hepatosomatic indexes of N. granulata juveniles from the three studied populations cultured in laboratory and fed with five experimental diets that molted three times. References as in Fig. 2. Numbers on bars indicate the a posteriori paired comparisons among diets (Holm-Sidak test); same number signifies no differences between pairs $(p>0.05)$. Horizontal bars indicate results of a posteriori paired comparisons (Holm-Sidak test) among populations; bars join no different groups $(p>0.05)$

appeared in N. granulata performance among crabs from the three populations in most of the measured variables, some traits varied significantly, as the time to first molt, the final crab size achieved and the HSI. In all cases, high similarity appears between SAO and RSJ, differing from $\mathrm{MC}$ (both of them or at least RSJ). The first difference, time until first molt in laboratory indicates on one hand that some degree of synchronicity exists among individuals of each population in molting, probably associated to synchronic settlement events, and on the other, that SAO and RSJ molting are in phase. Differences in the other two traits, final size and HIS, imply differences in physiology among populations. This scheme of differences/ similarities agrees with the model of genetic differentiation of isolation-by-distance (with gene flux restricted to neighbor localities) proposed by Ituarte et al. [8] for $N$. granulata: SAO and RSJ populations showed no genetic differences between them but both differed from MC. At the same time, growth performance of SAO-RSJ individuals suggests a higher efficiency than $M C$ based in the same resources, with the best growth rate and final average size. The HSI variations observed among populations can be interpreted in the same context, since individuals from MC cumulated fewer reserves in their digestive glands in the same period after molting compared to those from SAO/RSJ when fed with low protein diets; in other words, they needed more time to equal HIS values of southern populations, with low N diets. Such difference suggests a lesser ability of the first group to store reserves and/or produce enzymes, the two main functions of digestive glands, in conditions of limited food resources. On the other hand, there was a trait invariable among populations: the higher HIS corresponded to the worse feeding conditions. An explanation of this may be that the digestive gland weight did not differ so noticeably among diets, although crabs fed with an insufficient diet were lighter, probably due mainly to lesser muscular growth,. Accordingly, although some protein cumulated in digestive glands when diets were rich enough, carbon, accounting about $60 \%$ of the gland mass, was constant, as indicated by $\mathrm{C}$ and $\mathrm{N}$ analysis.

Experimental cultures evolving Drosophila melanogaster flies in conditions of nutritional stress [12] produced lines adapted to this condition with an enhanced larval growth rate. Additionally, Bochdanovits and de Jong [4] evolved D. melanogaster in a combination of low and high resources and low and high temperature. The combination of low temperature and low resources leaded the experimentally selected flies' line to a higher adult body size in regular conditions of feeding. When populations of $N$. granulata from $\mathrm{MC}$ and SAO were compared [2] the expected correlation between size and latitude/temperature was not found: individuals from SAO, near the southern limit of distribution of the species (higher latitude) were smaller than the low latitude population, instead of bigger as expected according Bergmann's rule. This biogeographical rule predicts an increase in body size at higher latitudes, as occurs in the clinal pattern of variation observed in other intertidal crabs for example Cyclograpsus cinereus in Chilean coasts [16] and Uca uruguayensis in Brazilian and Argentinean coasts [5]. The finding of RSJ population, with the biggest sizes recorded for the species, at only one degree southern latitude than SAO but with a better food quality [26] may be an example of the paradox described by Atkinson and Sibly [1] as a result of the combined effects of food quality and temperature. Although the involved mechanisms are not clear, it has been shown that animals from populations living at lower temperatures tend to reach bigger sizes, while low levels of food tend to the 

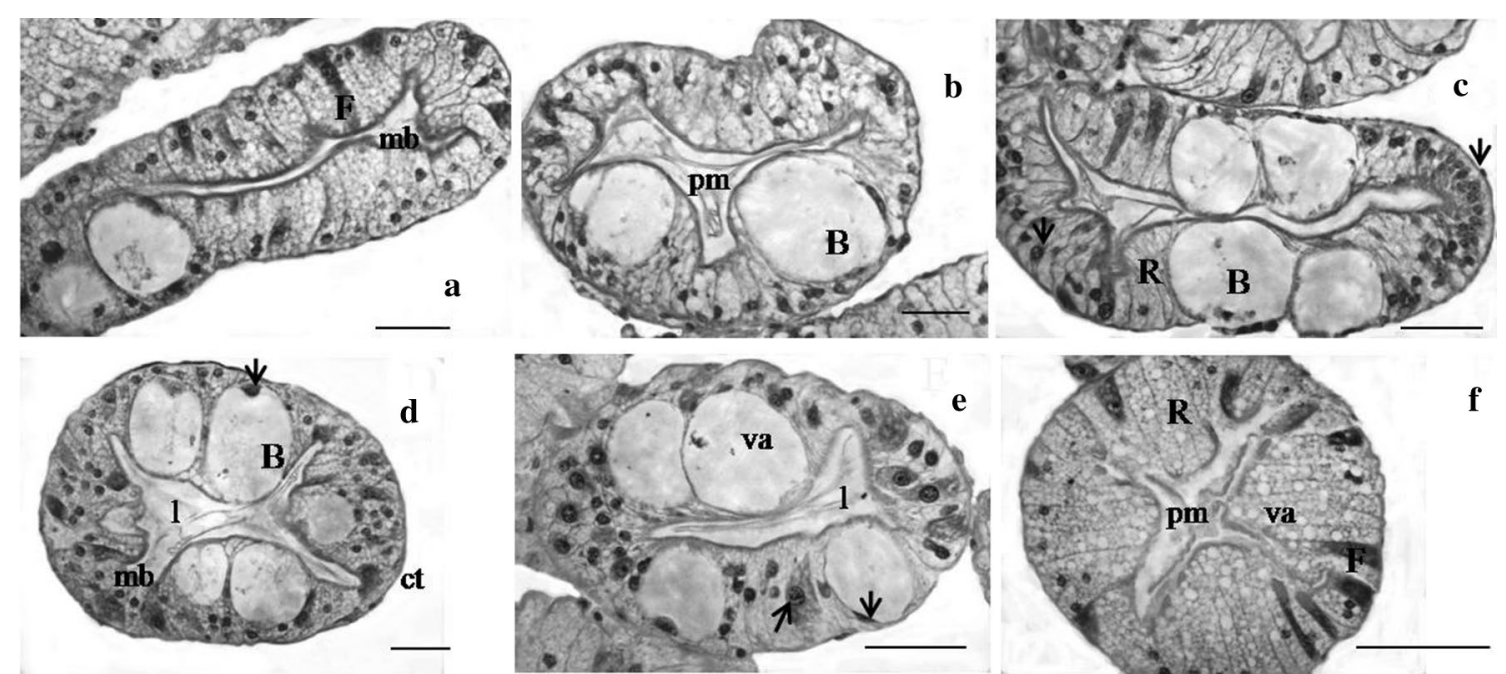

Fig. 8 Sections of tubules from the digestive gland of $N$. granulata juveniles stained with $H / E$. a $M C \operatorname{diet} A ; \mathbf{b} S A O \operatorname{diet} A ; \mathbf{c} R S J \operatorname{diet} A ; \mathbf{d} M C \operatorname{diet} E ;$ e SAO diet D; f RSJ diet E. Scale bar $50 \mu \mathrm{m}$. B blister-like cell, F fibrillar cell, R resorptive cell, ct connective tissue, / lumen, mb microvillous border, nu nucleous, pm peritrophic membrane, va vacuole

opposite, although being more efficient in energy allocation to growth. We propose that the observed differences between MC and SAO-RSJ populations come from local adaptation to a context of low or limited resources present at SAO (the main San Matias gulf population, 70 times larger than RSJ, [26]), where an enhanced efficiency in one or some of the diverse physiological processes involved in resources acquisition and/or allocation could have been selected. In consequence, since SAO and RSJ did not differ genetically and are probably connected via larval movements, the observed differences in morphological traits between SAO and RSJ populations, preliminarily reported by Spivak et al. [26] (higher maximal size, fecundity and reproductive output) should be the result of different environmental conditions, i.e.: phenotypic plasticity, as it was suggested in that study.

Neohelice granulata is an amphibious species, living alternately under and out of water (marine or brackish), and able of breathing and feeding in both environments. They eat mainly fresh leaves of halophytic plants (being able to degrade cellulose; [14]) and sediments (and the small organisms contained in it as crustaceans and foraminiferans) $[3,14,15]$. Both types of food are of low quality, being most of the organic components carbohydrates, with a very small proportion of protein (about $5 \%$ in fresh plants and even lower in sediments, [15]). Therefore, the diet of $N$. granulata matches well with those described for more strictly herbivorous land crabs reviewed by Linton and Greenaway [17], which adapt their digestive apparatus, metabolism and life cycle to a low nitrogen intake.
The response of individuals from the three populations of N. granulata to the different diets is not surprising since a higher growth is expected when protein content rises (e.g. [21, 27]). Nevertheless, the minimum protein level allowing growth in $N$. granulata juveniles is extremely low compared with more carnivorous decapod species, commonly assayed for optimal protein content of diets, in which protein contents below $15 \%$ are not tested, since they preclude not only growth but survival (e.g. [27]).

One of the adaptations typical of herbivorous land crabs is a relatively slow growth compared to more carnivorous aquatic species. In this regard, Luppi et al. [18] compared growth of juvenile $N$. granulata and Cyrtograpsus angulatus, another grapsoid aquatic euryhaline crab from MC, from megalopae to stage 8 juveniles. Individuals were fed with high protein live diet (Artemia sp. early nauplii). Intermolt periods of $N$. granulata were always longer, increasing gradually up to double the values of $C$. angulatus at stages 5 or 6 , while increment per molt was half that observed in $C$. angulatus. This result indicates that $N$. granulata growth can be considered slow (both in time and size increment per molt), even when fed with high quality diets, compared to a more carnivorous aquatic species as $C$. angulatus [23]. Additionally, the similarity of intermolt periods of crabs fed with 18 and $24 \%$ protein in this study suggest that $N$. granulata fed with diets above $18 \%$ protein molt as frequently as possible for a certain size and temperature, and growth cannot be substantially accelerated by higher quality diets. The same is true for size increment 
per molt, since no differences appeared between diets $\mathrm{D}$ and $\mathrm{E}$ and similar values were obtained in individuals fed with live Artemia spp. nauplii [18] or Artemia spp. nauplii and frozen Idotea baltica [19]. Consequently, per molt increment could not be improved by an increase in diet protein content. The nutritional conditions offered by diets $\mathrm{A}, \mathrm{B}$ and $\mathrm{C}$ in contrast, can be considered suboptimal, still allowing growth without increasing mortality (at least during a 7 months lapse), but lengthening the intermolt period and diminishing growth.

The normal development of digestive gland tubules in crabs fed with all tested diets agree with the idea of a species well adapted to a usually low quality diet. It is known for this species the opportunistic predator/cannibalistic behaviors as a way of improve the $\mathrm{N}$ intake $[3,13]$, although it was unclear to what extent such consumptions are necessary to growth. We have shown that crabs (at least juveniles) are able of survive and even growth for a period of 7 months relying exclusively on a diet with $3 \%$ of protein and $3 \%$ of lipids. This could explain in part the high densities and dominance of $N$. granulata in the intertidal areas they inhabit and where they play a significant role by shaping the habitat and affecting remarkably the community structure.

\section{Authors' contribution}

CB designed the experiments, prepared diets, participated in animal collecting, culturing and processing and drafted manuscript; TL participated in animal collecting, culturing and processing and analyzed data; ES contributed to discussion and corrected the manuscript. All authors read and approved the final manuscript.

\section{Acknowledgements}

This study was funded by grants from Agencia Nacional de Promoción Científica y Tecnológica (PICT 763), Consejo Nacional de Investigaciones Científicas y Técnicas (PIP 112 201101-00830) and Universidad Nacional de Mar del Plata (EXA 711/14-15/E661)

Received: 1 September 2015 Accepted: 8 March 2016

Published online: 01 December 2016

\section{References}

1. Atkinson D, Sibly R. Why are organisms usually bigger in colder environments? Making sense of a life history puzzle. TREE. 1997;12:235-9.

2. Bas C, Luppi T, Spivak E. Population structure of the South American Estuarine crab, Chasmagnathus granulatus (Brachyura: Varunidae) near the southern limit of its geographical distribution: comparison with northern populations. Hydrobiologia. 2005;537:217-28.

3. Bas C, Lancia J, Luppi T, Méndez-Casariego A, Kittlein M, Spivak E. Influence of tidal regime, diurnal phase, habitat and season on feeding of an intertidal crab. Mar Ecol. 2014;35:319-31. doi:10.1111/maec.12083.

4. Bochdanovits Z, De Jong G. Experimental evolution in Drosophila melanogaster interaction of temperature and food quality selection regimen. Evolution. 2003;57:1829-36.

5. Hirose G, Fransozo V,Tropea C, Lopez-Greco L, Negreiros-Fransozo M. Comparison of body size, relative growth and size at onset sexual maturity of Uca uruguayensis (Crustacea: Decapoda: Ocypodidae) from different latitudes in the south-western Atlantic. J Mar Biol Ass UK 2013:93:781-8. doi:10.1017/S0025315412001038.
6. Isacch J, Costa C, Rodríguez-Gallego L, Conde D, Escapa M, Gagliardini D, Iribarne O. Distribution of saltmarsh plant communities associated with environmental factors along a latitudinal gradient on the south-west Atlantic coast. J Biogeogr. 2006;33:888-900.

7. Ituarte R, Bas C, Luppi T, Spivak E. Interpopulational differences in the female reproductive cycle of the Southwestern Atlantic estuarine crab Chasmagnathus granulatus (Brachyura: Grapsoidea: Varunidae). Sci Mar. 2006;70:709-18.

8. Ituarte R, D'Anatro A, Luppi T, Ribeiro P, Spivak E, Iribarne O, Lessa E. Population structure of the SW Atlantic estuarine crab Neohelice granulata throughout its range: a genetic and morphometric study. Estuaries Coast. 2012;35:1245-60. doi:10.1007/s12237-012-9516-9.

9. Karasov W, Martínez del Rio C. Physiological ecology. How animals process energy, nutrients, and toxins. New Jersey: Princeton University Press; 2007.

10. Kawecki T, Ebert D. Conceptual issues in local adaptation. Ecol Lett. $2004 ; 7: 1225-41$.

11. Klein Breteler W. Laboratory experiments on the influence of environmental factors on the frequency of moulting and the increase in size at moulting of juvenile sore crabs, Carcinus maenas. Neth J Sea Res. 1975;9:100-20.

12. Kolss M, Vijendravarma RK, Schwaller G, Kawecki TJ. Life-history consequences of adaptation to larva nutritional stress in Drosophila. Evolution. 2009;63:2389-401.

13. Lancia J. Ecología y Fisología alimentaria del cangrejo Neohelice granulata. Ph. D. Thesis. Universidad Nacional de Mar del Plata, Mar del Plata; 2013.

14. Lancia J, Fernández-Giménez A, Bas C, Spivak E. Adaptive differences in digestion enzyme activity in the crab Neohelice granulata in relation to sex and habitat. J Crust Biol. 2012;32:940-8.

15. Lancia J, Bas C, Spivak E. Food manipulation and selection in the omnivorous grapsoid crab Neohelice granulata (Decapoda: Varunidae). Sci Mar. 2014;78:529-36.

16. Lardies MA, Arias MB, Bacigalupe LD. Phenotypic covariance matrix in life-history traits along a latitudinal gradient: a study case in a geographically widespread crab on the coast of Chile. Mar Ecol Prog Ser. 2010;412:179-87.

17. Linton S, Greenaway P. A review of feeding and nutrition of herbivorous land crabs: adaptations to low quality plant diets. J Comp Physiol B. 2007;177:269-86.

18. Luppi T, Spivak E, Anger K. Postsettlement growth of two estuarine crab species, Chasmagnathus granulata Dana, 1851 and Cyrtograpsus angulatus Dana, 1851 (Crustacea, Decapoda, Grapsidae): laboratory and field investigations. Helgol Mar Res. 2001;55:293-305.

19. Luppi T, Spivak E, Bas C, Anger K. Molt and growth of an estuarine crab, Chasmagnathus granulatus (Brachyura: Varunidae), in Mar Chiquita coastal lagoon, Argentina. J Appl Ichthyol. 2004;20:333-44.

20. Luppi T, Bas C, Mendez Casariego A, Albano M, Lancia J, Kittlein M, Rosenthal A, Farías N, Spivak E, Iribarne O. The influence of habitat, season and tidal regime in the activity of the intertidal crab Neohelice (= Chasmagnathus) granulata. Helgol Mar Res. 2013;67:1-15.

21. MuY, Shim K, Guo J. Effect of protein level in isocaloric diets on growth performance of the juvenile Chinese hairy crab, Eriocheir sinensis. Aquaculture. 1998;165:139-48.

22. Pigliucci M. Phenotypic plasticity: beyond nature and nurture. Baltimore: Johns Hopkins University Press; 2001.

23. Rodríguez-Graña L, Calliari D, Conde D, Sellanes J, Urrutia R. Food web of a SW Atlantic shallow coastal lagoon: spatial environmental variability does not impose substantial changes in the trophic structure. Mar Ecol Prog Ser. 2008;362:69-83. doi:10.3354/meps07401.

24. Sanford E, Kelly W. Local adaptation in marine invertebrates. Annu Rev Mar Sci. 2011;3:509-35. doi:10.1146/annurev-marine-120709-142756.

25. Sassi P, Caviedes-Vidal E, Anton R, Bozinovic F. Plasticity in food assimilation, retention time and coprophagy allow herbivorous cavies (Microcavia australis) to cope with low food quality in the Monte desert. Comp Biochem Physiol A. 2010;155:378-82. doi:10.1016/j.cbpa.2009.12.007.

26. Spivak E, Bas C, Luppi T (2014) Phenotypic differences between crab populations inhabiting close but contrasting habitats. Neohelice granulata as a case study. In: 8th international crustacean congress (ICC-8). Frankfurt. Alemania. 
27. Unnikrishnan U, Paulraj R. Dietary protein requirement of giant mud crab Scylla serrata juveniles fed iso-energetic formulated diets having graded protein levels. Aquac Res. 2010;41:278-94. doi:10.1111/j.1365-2109.2009.02330.x.
28. Vogt G, Storch V, Quinitio ET, Pascual FP. Midgut gland as monitor organ for the nutritional value of diets in Penaeus monodon (Decapoda). Aquaculture. 1985;48:1-12.
Submit your next manuscript to BioMed Central and we will help you at every step:

- We accept pre-submission inquiries

- Our selector tool helps you to find the most relevant journal

- We provide round the clock customer support

- Convenient online submission

- Thorough peer review

- Inclusion in PubMed and all major indexing services

- Maximum visibility for your research

Submit your manuscript at www.biomedcentral.com/submit
() Biomed Central 